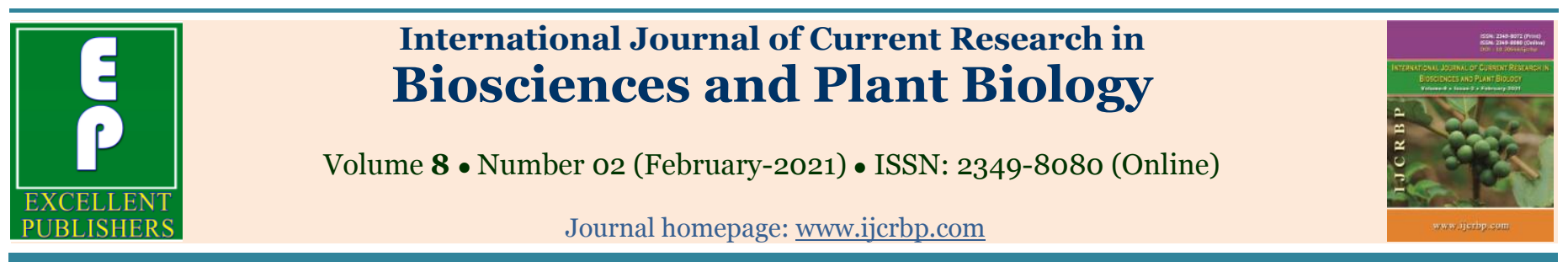

\title{
Effectiveness of Anonidium mannii seed extracts against Colletotrichum lindemuthianum and Fusarium solani, agents responsible for anthracnose and fusariose of common beans (Phaseolus vulgaris L.) in the Centre region-Cameroon
}

\author{
Manga Anaba Désiré ${ }^{1}{ }^{1}{ }^{2}$, Ndongo Bekolo ${ }^{1}$, Biye Elvire Hortense ${ }^{2}$, \\ Kuate Tueguem William Norbert ${ }^{1}$, Ngatsi Zemko Patrice ${ }^{1}$, Ngono Ambassa Véronique ${ }^{2}$ \\ ${ }^{I}$ The laboratory of Phytopathology and Crop Protection, Department of Plant Biology, Faculty of Science, \\ University of Yaoundé I, PO Box 812, Yaoundé-Cameroon \\ ${ }^{2}$ The laboratory of Environmental Management and Plant Production, Department of Plant Biology, Faculty of Science, \\ University of Yaoundé I, PO Box 812, Yaoundé-Cameroon
}

*Corresponding author; e-mail: desiremanga62@gmail.com

\begin{tabular}{|c|c|}
\hline Article Info & Abstract \\
\hline $\begin{array}{l}\text { Keywords: } \\
\text { Anonidium mannii } \\
\text { Antifungal activities } \\
\text { Colletotrichum } \\
\quad \text { lindemuthianum } \\
\text { Fusarium solani } \\
\text { Phaseolus vulgaris }\end{array}$ & $\begin{array}{l}\text { Anthracnose and Fusariose of beans caused by Colletotrichum lindemuthianum and Fusarium solani } \\
\text { respectively are two dreaded diseases that can lead to yield losses of } 30 \text { to } 100 \% \text { in the field. The } \\
\text { present study was carried out to evaluate the antifungal activities of seed extracts of Anonidium mannii } \\
\text { (Annonaceae) on the in vitro growth of } C \text {. lindemuthianum and } F \text {. solani. Extracts of } A \text {. mannii seeds } \\
\text { obtained from acetone, water and methanol solvents, were used for phytochemical screening and for } \\
\text { the preparation of solutions with concentrations of } 12.5,25 \text { and } 50 \mu 1 / \mathrm{ml} \text {. To evaluate radial growth, } \\
\text { explants of } 0.7 \mathrm{~cm} \text { diameter each were obtained from two strains of } C \text {. lindemuthianum and two strains } \\
\text { of } F \text {. solani. They were placed each at the centre of sterile Petri dishes containing the PDA medium } \\
\text { supplemented with the different concentrations of extracts and incubated at } 23^{\circ} \mathrm{C} \text { for } 6 \text { days. The } \\
\text { results of the phytochemical screening revealed the presence of alkaloids, phenols, saponins in the } A \text {. } \\
\text { mannii seed extracts and this depended on the solvent used. The minimum inhibitory concentrations } \\
\text { (MIC } \text { MI }_{50} \text { and } \mathrm{MIC}_{90} \text { ) were also calculated. At a concentration of } 50 \mu 1 / \mathrm{ml} \text { each, acetone extract inhibited } \\
\text { the growth of strain } 2 \text { of } C \text {. lindemuthianum }(2.33 \mathrm{~cm} \text { ) more than the methanol extract }(3.26 \mathrm{~cm} \text { ) in six } \\
\text { days of incubation. Similarly, the growth of strain } 2 \text { of } F \text {. solani was strongly inhibited by methanol } \\
\text { extract ( } 1.98 \mathrm{~cm} \text { ). The MIC } \text { S }_{50} \text { of the aqueous extract gave } 27.38 \mu 1 / \mathrm{ml} \text { with } F \text {. solani and } 32.24 \mu 1 / \mathrm{ml} \\
\text { for the acetone extract with } C \text {. lindemuthianum. Due to their antifungal power, after purification with } \\
\text { bioactive compounds, the aqueous, acetone and methanol extracts revealed by the phytochemical } \\
\text { screening could be used as synthetic fungicides for the control of anthracnose and fusariose of } \\
\text { common bean. }\end{array}$ \\
\hline
\end{tabular}

- Received: 01 November 2020 • Revised: 11 January 2021 • Accepted: 15 January 2021 • Published Online: 6 February 2021 


\section{Introduction}

An increase in bean production is observed in Africa due to a high demand from local and regional markets (Snapp et al., 2018; Kebede et al., 2020). In 2018, dry bean production in Central Africa was 1.08 million tons from 1.7 million hectares. In Cameroon, this production is 0.4 million tons on 0.3 million hectares. The average consumption of chemical pesticides for bean production is $0.04 \mathrm{~kg} / \mathrm{ha}$ and $0.18 \mathrm{~kg} / \mathrm{ha}$ respectively in Central Africa and Cameroon (FAO, 2020). Cryptogamic diseases, especially anthracnose and fusariose, are responsible for estimated yield losses of more than 1 million tons per year in sub-Saharan Africa, where chemicals are not readily available to smallholder farmers (PROTA, 2015). Despite the variety, beans grow in both forest and high altitude zones of Cameroon (IRAD, 2013). Diversed climatic and ecological conditions favour the proliferation of anthracnose and fusariose caused by Colletotrichum lindemuthianum and Fusarium solani f. sp. Phaseoli, (Meddah et al., 2011; Rakotoarimanga et al., 2014; LeClair et al., 2015; Faucher et al., 2018). In the absence of appropriate phytosanitary control, $F$. solani $\mathrm{f}$ sp. phaseoli is the most predominant and damaging pathogen due to its durability and viability (Katan, 2017; Mukamuhirwa et al., 2018). Its damage in the field can result in yield losses of up to $84 \%$ of common beans (Phaseolus vulgaris L.) (Mukankusi, 2008; Wakesho et al., 2008; Schneider et al., 2001; Coleman, 2016; Kimberly et al., 2020). Due to $C$. lindemuthianum, production losses are estimated at about $50 \%$ in the Great Lakes region of Central Africa (Autrique et al., 1989) and $72.19 \%$ in cashew nuts in Benin (Houndahouan et al., 2018). Chemical control remains the main measure to counteract the action of pathogens responsible for cryptogamic diseases, due to the high consumption of synthetic pesticides which raised imports to 20,338 tons for 100.87 million US\$ in 2018 in Cameroon (CTNBC, 2020). The increased use of chemical pesticides in the agricultural sector can be explained by the poor sensitization of research results. This is also caused by the users' ignorance of the existence of biological control measures which can eliminate or at least reduce environmental damage, investment costs and contribute to the protection of humans and the conservation of biodiversity (Ambang, 1996; CIAT, 2006).

Various research studies have shown the efficiency of plant extracts against pathogenic fungi of the genera Colletotrichum and Fusarium, and a pronounced antifungal activity has been observed against Fusarium oxysporum by aqueous extracts of Lantana camara (Adjou and Soumanou, 2013) and Combretum racemosum (Zirihi et al., 2008). Essential oil from Enantia chlorantha, an Anonaceae from Cameroon, has a significant activity against Fusarium moniliforme (Nyeguea et al., 2008). Aqueous extracts of Calycotome spinosa stems have a significant antifungal activity against Alternaria solani and Alternaria altenata, plant pathogens of stored wheat (Alleche, 2017). Ethyl acetate extracts of $L$. camara, savory and thyme oils, aqueous and ethanol extracts of Azadiratcha indica and Jatropha curcas have an antifungal activity on Colletotrichum gloeosporioides, which causes anthracnose in paw-paw, yam and mango (Ademe, 2013; Sarkhosh et al., 2018; Kwowura et al., 2019; Zakaria et al., 2020).

Because of their availability to farmers, non-toxicity to humans and the environment, and their biodegradability, plant extracts with pesticidal potential have been explored as sources of biological alternatives to chemical pesticides. Among these biological alternatives for controlling leguminous fungal diseases, some aqueous or organic extracts have been obtained from the plant organs with medicinal properties. A. mannii (Anonaceae), a native plant of tropical Africa and Central and West Africa specifically, is a dense and gallery forest fruit tree known for its therapeutic and medicinal uses (Betti, 2003; Jiofack et al., 2009; Dibong et al., 2015; Paluku et al., 2019; Konda et al., 2012; Mokale et al., 2020). Thus, the purpose of this work is to evaluate the effectiveness of aqueous and organic extracts of $A$. mannii seeds on the growth of $C$. lindemuthianum and $F$. solani $\mathrm{f}$. sp. phaseoli in vitro.

\section{Materials and methods}

\section{Plant material}

The plant material consisted of A. mannii seeds whose mature fruits were collected in the forests of Mfou, Mefou et Afamba divisions in the Centre- region Cameroon and transported to the Phytopathology laboratory of the University of Yaoundé 1 . These fruits were pulped to obtain seeds that were dried at room temperature for 4 to 5 weeks.

\section{Fungal material}

C. lindemuthianum and $F$. solani were isolated from leaves and stems of diseased common beans taken from 
experimental fields that had not been subjected to any phytosanitary treatment at Akonolinga ( $\mathrm{N} \mathrm{03} 3^{\circ} 48^{\prime} 13^{\prime \prime}$ and E $012^{\circ} 15^{\prime} 37^{\prime \prime}$, altitude 674m) and Leboudi (N 03 $54^{\circ} 54^{\prime \prime}$ and E $11^{\circ} 26^{\prime} 27^{\prime \prime}$ altitude $795 \mathrm{~m}$ ) located in the Centreregion Cameroon.

\section{Chemical material}

The chemical material was a synthetic fungicide called Monchamp 720 WP, whose main ingredient is Cymoxanil (120 g/kg) + Mancozèbe $(600 \mathrm{~g} / \mathrm{kg})$, with a formulation of $3.33 \mathrm{~g} / 1$.

\section{Preparation of $A$. mannii seed extracts}

The seeds of $A$. mannii have been crushed using a Victoria hand mill to obtain a brown powder. The organic extracts were prepared by macerating $500 \mathrm{~g}$ of powder in 2 liters of solvent (acetone, methanol) for 72 hours (Stoll, 1994) and then filtered. The filtrates obtained were concentrated in a rota-steamer and the extracts obtained were kept at $-4^{\circ} \mathrm{C}$ in the refrigerator till their use. For aqueous extraction, the powder is wrapped in muslin cloth and soaked directly in water for 12 hours and then wrung out (Stoll, 1994; Ambang et $a l ., 2009,2010)$ and the extract obtained is used directly.

For each extract, the extraction yield was calculated using the formula below quoted by Ngoh Dooh et al. (2014).

$$
\text { Yield }(\%)=\frac{\text { Mass of extract }(\mathrm{g})}{\text { Mass powder }(\mathrm{g})} \times 100
$$

\section{Phytochemical screening}

Secondary metabolites present in the aqueous and organic extracts of $A$. mannii seeds were determined by adapting the standard procedures described by Harbone (1973), and Edeoga et al. (2005). These techniques are based on the appearance of color, precipitation and foam in the presence of the different reagents characterizing each class of secondary metabolites.

Thus, their presence has been indicated by the appearance of: persistent and thick foam for saponins; white precipitates for phenols, pale yellow for alkaloids, purple red for terpenes, dark blue for tannins and greenish blue precipitates for sterols.

\section{Isolation and purification of $C$. lindemuthianum and F. solani}

The pathogens (2 strains for each pathogen) were isolated from the leaves and stems of diseased common beans showing symptoms of anthracnose or fusariose. Fragments from plant organs of about $2 \mathrm{~cm}^{2}$ were disinfected with $70 \%$ ethyl alcohol for 2 minutes and then with 5\% sodium hypochlorite solution for 5 minutes. These fragments were then rinsed three times with sterile distilled water and dried under a hood on hydrophilic paper; then four fragments were placed in a Petri dish containing the PDA (Potatoes Dextrose Agar) culture medium supplemented with antibiotics including ampicillin 250mg/l and nystatin 20mg/l (Djeugap et al., 2009; Tsopmbeng et al., 2012). Pathogen colonies visible around the fragments after three days of incubation in the laboratory at $23^{\circ} \mathrm{C}$, were collected and transferred to Petri dishes containing the previously prepared PDA culture medium. Morphologically pure cultures of the mycelium and fruiting bodies were obtained after several replicates using the slightly modified Brooks (2005) and Scot et al., (2011) method. Morphological criterion such as growth rate was used to characterize the strain obtained (Ondo, 2006).

\section{In vitro evaluation of the antifungal activity of crude extracts}

The in vitro evaluation of the antifungal activity of the extracts was carried out on two strains of each phytopathogen at concentrations of 12.5, 25 and $50 \mu \mathrm{g} / \mathrm{ml}$ for the organic and aqueous extracts from stock solutions of $500 \mu \mathrm{g} / \mathrm{ml}$. A synthetic fungicide, Monchamp $720 \mathrm{WP}$ based on Cymoxanil $(120 \mathrm{~g} / \mathrm{kg})+$ Mancozèbe $(600 \mathrm{~g} / \mathrm{kg})$, was used as a positive control by taking $1 \mathrm{~g}$ of the powder for $5 \mathrm{ml}$ of distilled water from a $50 \mathrm{~g}$ sachet.

Mycelial explants of $C$. lindemuthianum and $F$. solani, $0.7 \mathrm{~cm}$ in diameter, were punched from a seven-day old pure fruit culture and placed at the centre of the Petri dish containing the media with the various extracts or chemical fungicide. A negative control not supplemented with extract was developed. Each treatment was repeated three times. Incubation was carried out at $23^{\circ} \mathrm{C}$ under a photoperiod of $12 / 12$ for one week. Every two days, the radial growth diameter of each cultured explants was measured and this continued until the mycelium filled the control boxes. The radial growth of the pathogen was assessed by measuring two 
perpendicular diameters plotted on the back of the Petri dish. The radial growth of the fungus was obtained by subtracting the diameter of explant from the average of the two perpendicular diameters using the formula proposed by Dohou et al. (2004):

$$
\mathrm{D}=\frac{\mathrm{D} 1+\mathrm{D} 2}{2}-\mathrm{D} 0
$$

Where,

D0 is the diameter explant; D1 and D2 are the diameters of culture measured in the two perpendicular directions.

The inhibition rate (I \%) due to each extract is evaluated in relation to the mycelial growth in the control boxes according to the formula proposed by Dohou et al. (2004).

$$
\mathrm{I}(\%)=\frac{\operatorname{Dco}(\mathrm{mm})-\mathrm{Dxi}(\mathrm{mm})}{\text { Dco }(\mathrm{mm})} \times 100
$$

Where,

I (\%): percentage of inhibition; Dco is the average diameter of the control batch and Dxi the average diameter of the batches in the presence of the extract.

\section{Statistical analysis}

The radial inhibition growth percentages of the pathogens were transformed into probits. The effectiveness of the extracts was evaluated on the basis of the minimum inhibition concentration value of $50 \%$ $\left(\mathrm{MIC}_{50}\right)$ and $90 \%\left(\mathrm{MIC}_{90}\right)$ determined after 6 days of growth according to the formula proposed by Finney (1971). The radial growth data was subjected to variance analysis using $\mathrm{R}$ software version 3.5.1 and the means were separated by Tukey's multiple test (P> $0.05)$.

\section{Results}

\section{Extraction yield}

The yield and characteristics of the different extracts obtained depended on the solvent used for extraction (Table 1). Extraction with methanol gave the highest yield of $32.89 \%$ compared to acetone $(14.67 \%)$ and an average yield of $25.40 \%$ was obtained for extraction with water. All three extracts are brown in color; those with acetone and methanol are viscous while those with water are fluid.

\section{Phytochemical screening of extracts}

The presence of compounds belonging to the five families of alkaloids, phenols, saponins, tannins, sterols and triterpenes were revealed. Alkaloids are abundant in extracts with acetone, water and methanol. Phenols and saponins are abundant in the aqueous extract, present in the acetone extract and absent in the methanol extract. Sterols and triterpenes are present in the aqueous extract, abundant in the acetone extract and very abundant in the methanol extract. Tannins are present in the aqueous and acetone extracts, but absent in the methanol extract. Anthraquinones and flavonoids are completely absent in all A. mannii seed extracts (Table 2).

Table 1. Extraction yield and characteristics of the extracts obtained with $500 \mathrm{~g}$ of seeds.

\begin{tabular}{lll}
\hline Extract & Yield (\%) & Characteristic \\
\hline Acetone (AcE) & 14.67 & Clear brown and viscous \\
Methanol (ME) & 32.89 & Brown and very viscous \\
Water (AqE) & 25.40 & Brown and liquid \\
\hline
\end{tabular}

AcE: Acetone extract; ME: Methanol extract; AqE: Aqueous extract.

Table 2. Phytochemical composition of different extracts of A. mannii.

\begin{tabular}{llll}
\hline Phytochemicals & AcE & ME & AqE \\
\hline Alkaloids & ++ & ++ & ++ \\
Anthraquinones & - & - & - \\
Flavonoids & - & - & + \\
Phenols & + & - & ++ \\
Saponines & + & - & ++ \\
Tannins & + & - & + \\
Sterols and triterpenes & ++ & +++ & + \\
\hline
\end{tabular}

(-): absent; (+): present; (++): abundant; (+++): very abundant. AcE: Acetone extract; ME: Methanol extract; AqE: Aqueous extract. 


\section{Effect of A. mannii extracts on the radial growth of C. lindemuthianum}

Acetone extract inhibited the radial growth of strain 2 more than strain 1 of $C$. lindemuthianum after 6 days. Regardless of the strain, after the same duration, the controls showed the same level of growth of the two strains of $C$. lindemuthianum which completely filled the Petri dishes at $7.8 \mathrm{~cm}$ (Fig. 1). Generally, the inhibition of mycelial growth of $C$. lindemuthianum varies from one treatment to another. Seed extracts significantly inhibited the radial growth of $C$. lindemuthianum. At 6 days of incubation, at a concentration of $50 \mu \mathrm{l} / \mathrm{ml}$, acetone (2.71 and $2.33 \mathrm{~cm})$ and aqueous $(2.9$ and $2.56 \mathrm{~cm})$ extracts inhibited mycelial growth of strains 1 and 2 the most (Fig. 2A, 2B and 2C).

\section{Effect of $A$. mannii extracts on the radial growth of $F$. solani}

Inhibition of the radial growth of $F$. solani strains vary from one treatment to another. The different seed extracts significantly inhibited the radial growth of $F$. solani. At 6 of days incubation, at a concentration of 50 $\mu 1 / \mathrm{ml}$, the methanol extract $(3.15$ and $1.98 \mathrm{~cm})$ inhibited strains 1 and 2 respectively, followed by the aqueous extract $(4.21$ and $2.01 \mathrm{~cm})$ and the acetone extract $(4.35$ and $4.36 \mathrm{~cm}$ ) (Fig. 3A, 3B and 3C).

On the other hand, at the same date, the control dishes show the same level of radial growth of the mycelia of the two strains of $F$. solani, which completely filled the Petri dishes at $7.8 \mathrm{~cm}$ (Figs. 3A, 3B and 3C).
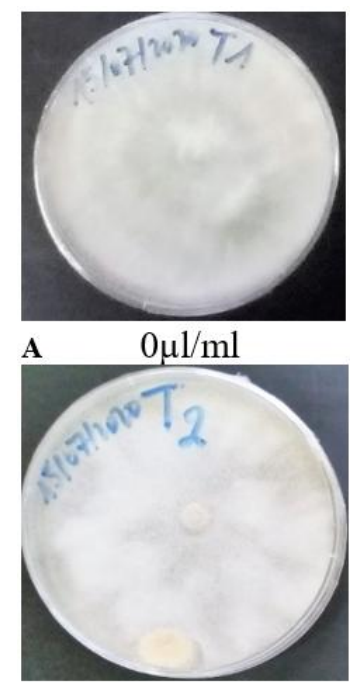

B

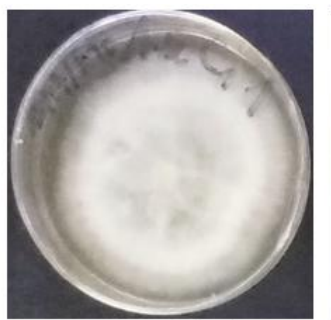

$12.5 \mu \mathrm{l} / \mathrm{ml}$

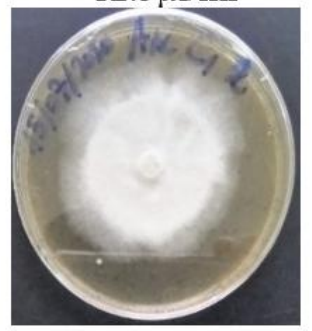

$12.5 \mu \mathrm{l} / \mathrm{ml}$

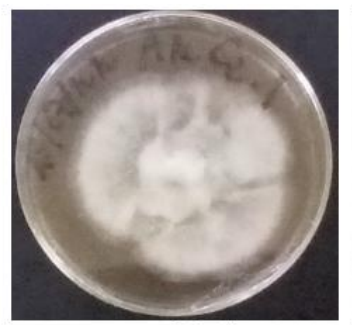

$25 \mu \mathrm{l} / \mathrm{ml}$

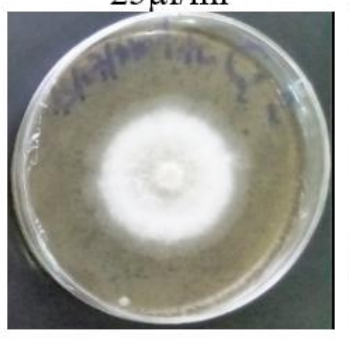

$25 \mu \mathrm{l} / \mathrm{ml}$

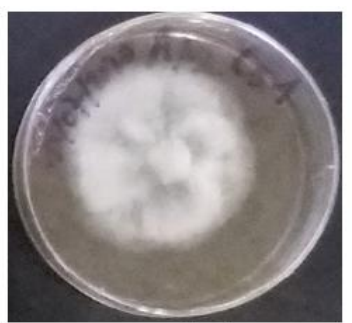

$50 \mu \mathrm{l} / \mathrm{ml}$

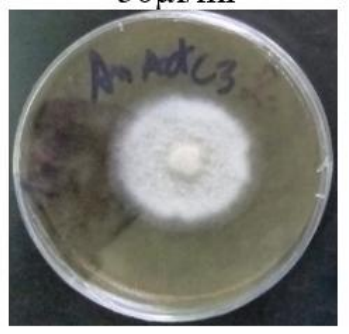

$50 \mu \mathrm{l} / \mathrm{ml}$

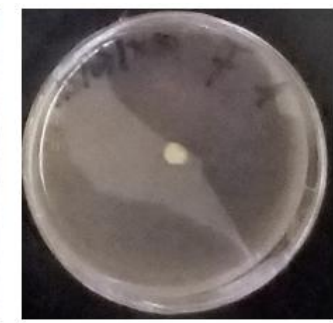

F

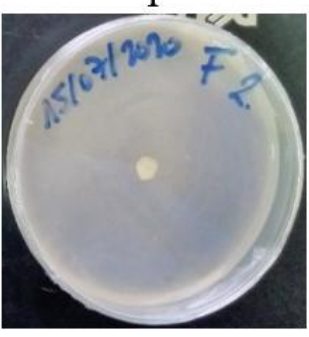

F

Fig. 1: Effect of acetone extract on radial growth of $C$. lindemuthianum strains, A: strain 1 B: strain 2.
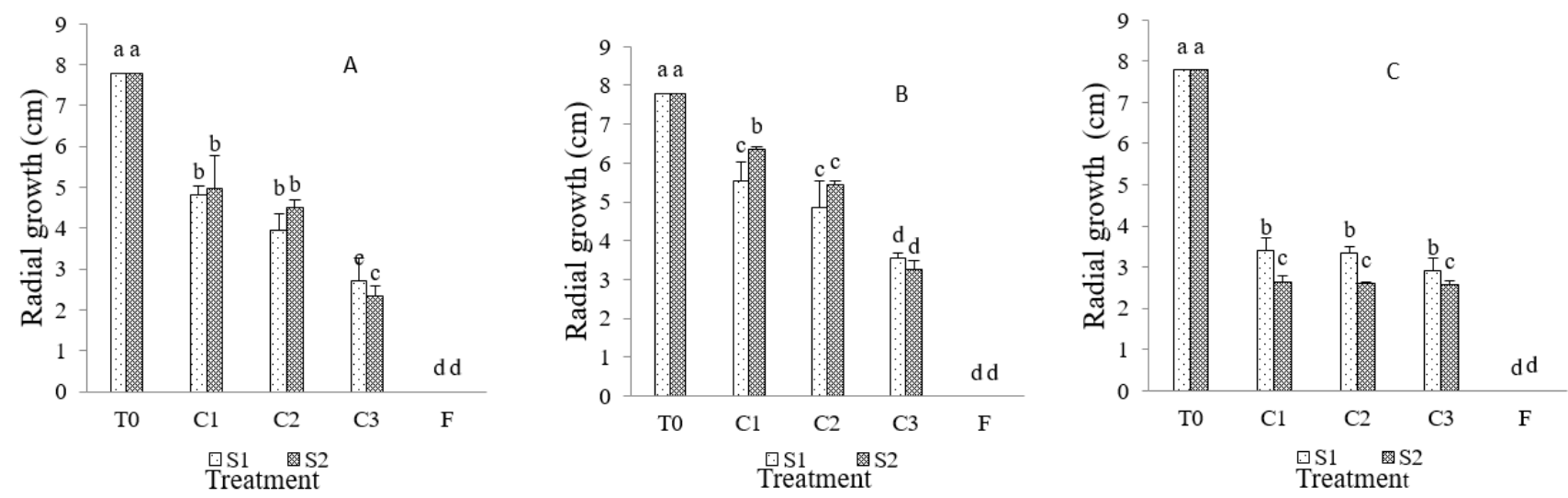

Fig. 2: Effect of seed extracts on mycelial growth of $C$. lindemuthianum at different concentrations. Histograms with the same letter do not have a significant difference at the threshold of $5 \%$. S1: strain $1 ; \mathrm{S} 2:$ strain $2 ; \mathrm{C} 0$ : $0 \mu \mathrm{l} / \mathrm{ml}$; C1: $12.5 \mu \mathrm{l} / \mathrm{ml}$; C2: $25 \mu \mathrm{l} / \mathrm{ml}$; C3: $50 \mu \mathrm{l} / \mathrm{ml}$ and $3.33 \mathrm{~g} / \mathrm{l}$ for F; AcE: Acetone extract; ME: Methanol extract; AqE: Aqueous extract; F: Chemical fungicide; T0: Negative control. 


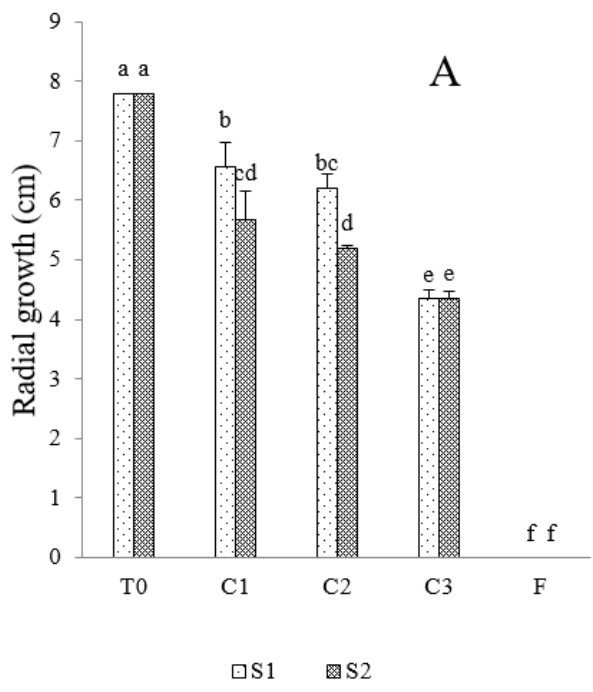

Treatment

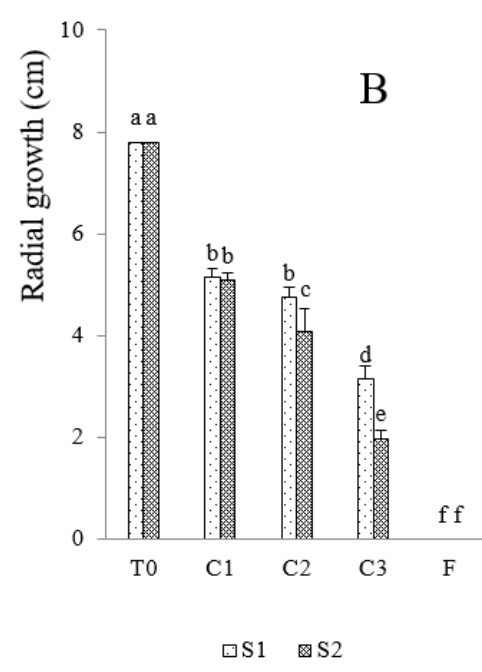

Treatment

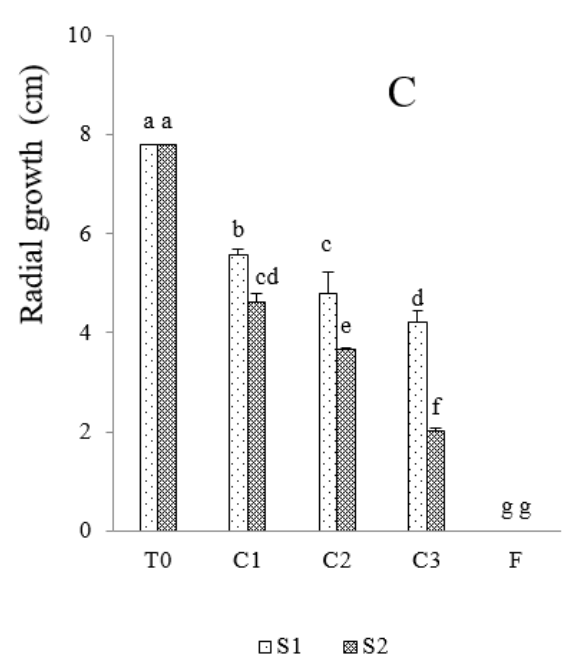

Treatment

Fig. 3: Effect of seed extracts on the mycelial growth of $F$. solani as a function of different concentrations. Columns with the same letter do not differ significantly at a threshold of 5\%. S1: strain 1; S2: strain 2; C0: $0 \mu \mathrm{l} / \mathrm{ml}: \mathrm{C} 1: 12.5 \mu 1 / \mathrm{ml}$; C2: $25 \mu \mathrm{l} / \mathrm{ml}$; C3: $50 \mu \mathrm{l} / \mathrm{ml}$ and 3.33g/l for F; AcE: Acetone extract; ME: Methanol extract; AqE: Aqueous extract; F: Chemical fungicide; T0: Negative control.

\section{Percentage inhibition of extracts}

The percentage inhibition of radial growth of strains 1 and 2 of $C$. lindemuthianum and $F$. solani increased with the concentration of the aqueous and organic extracts. At 6 days of incubation, there was complete inhibition with the chemical fungicide and the aqueous and organic extracts at the concentration of $50 \mu 1 / \mathrm{ml}$ for C. lindemuthianum but no inhibition with the negative control. At the same concentration, the percentage inhibition was highest for the aqueous and methanol extracts (Table 3 ).

Table 3. Percentage inhibition of seed extracts and synthetic fungicide on mycelial growth of $C$. lindemuthianum and $F$. solani.

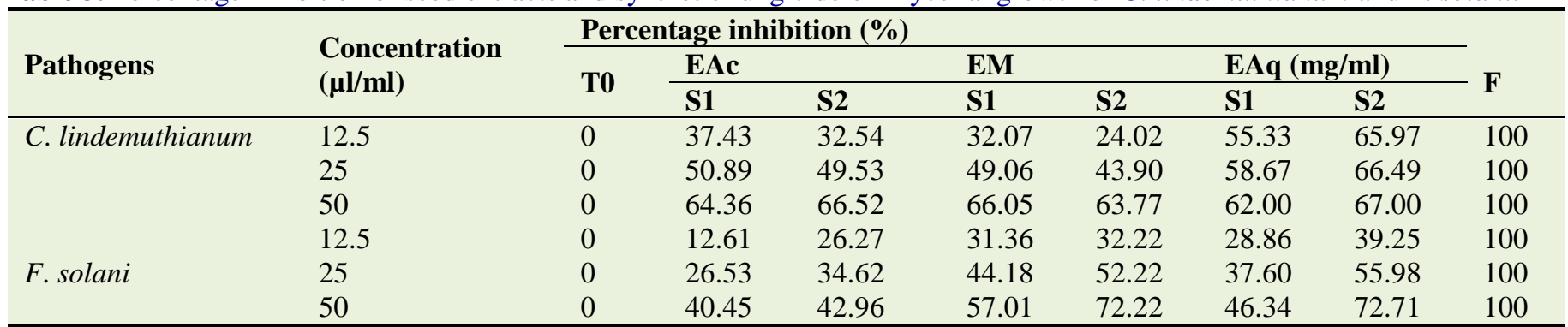

EAc: Acetone extract; EM: Methanol extract; EAq: Aqueous extract; T0: Negative control; S1: Strain 1; S2: Strain 2.

\section{Minimum inhibition concentrations of the different extracts}

The values of the minimum inhibitory concentrations $\left(\mathrm{MIC}_{50}\right.$ and $\left.\mathrm{MIC}_{90}\right)$ of the extracts are presented in Table 4. For $C$. lindemuthianum strains 1 and 2, the $\mathrm{MIC}_{50}$ minimum inhibition concentrations are higher with the methanol extract $(45.86 \mu \mathrm{l} / \mathrm{ml}$ and $45.42 \mu \mathrm{l} / \mathrm{ml})$ than with the acetone extract $(32.24 \mu \mathrm{l} / \mathrm{ml}$ and 33.79 $\mu 1 / \mathrm{ml}$ ), respectively, while the values with the aqueous extract are not determined. With regard to $\mathrm{MIC}_{90}$, the aqueous extract has the highest values $(91.9 \mathrm{mg} / \mathrm{ml}$ $84.17 \mathrm{mg} / \mathrm{ml}$ ), followed by the methanol extract $(78.4$ $\mu 1 / \mathrm{ml}$ and $58.97 \mu 1 / \mathrm{ml}$ ) and the acetone extract the lowest values $(61.77 \mu \mathrm{l} / \mathrm{ml}$ and $53.03 \mu \mathrm{l} / \mathrm{ml})$. For $F$. solani strains, $\mathrm{MIC}_{50}$ for strain $\mathrm{S} 2$ were lower for the aqueous $(27.38 \mu \mathrm{l} / \mathrm{ml})$ and methanol $(31.48 \mu \mathrm{l} / \mathrm{ml})$ extracts compared to the acetone extract $(44.09 \mu \mathrm{l} / \mathrm{ml})$.

For $F$. solani strain $\mathrm{S} 1, \mathrm{MIC}_{50}$ values are lower for the organic extracts $(41.50 \mu \mathrm{l} / \mathrm{ml}$ for the acetone extract, $40.91 \mu \mathrm{l} / \mathrm{ml}$ for the methanol extract) compared to the 
aqueous extract $(56.98 \mu \mathrm{l} / \mathrm{ml})$. $\mathrm{MIC}_{90}$ values are lowest with the methanol extract $(89.32 \mu \mathrm{l} / \mathrm{ml}$ and $64.82 \mu \mathrm{l} / \mathrm{ml})$ and highest with the acetone extract, $103.26 \mu \mathrm{l} / \mathrm{ml}$ and $74.02 \mu \mathrm{l} / \mathrm{ml}$ for the two strains respectively.

Table 4. $\mathrm{MIC}_{50}$ and $\mathrm{MIC}_{90}(\mu \mathrm{l} / \mathrm{ml})$ values on mycelial growth of strains of pathogens as a function of seed extracts.

\begin{tabular}{llllll}
\hline \multirow{2}{*}{ Pathogens } & \multirow{2}{*}{ Solvent } & MIC $_{\mathbf{5 0}}$ & & \multicolumn{2}{c}{ MIC $_{\mathbf{9 0}}$} \\
\cline { 3 - 6 } & & S1 & S2 & S1 & S2 \\
\hline C. lindemuthianum & Acetone & 32.24 & 33.79 & 61.77 & 53.03 \\
& Methanol & 45.86 & 45.42 & 78.40 & 58.97 \\
\multirow{5}{*}{ F. solani } & Water & nd & nd & 91.90 & 84.17 \\
& Acetone & 41.50 & 44.09 & 103.26 & 74.02 \\
& Methanol & 40.91 & 31.48 & 89.32 & 64.82 \\
\hline
\end{tabular}

nd: not determined, AcE: Acetone extract; ME: Methanol extract; AqE: Aqueous extract; T0: Negative control; S1: Strain 1; S2: Strain 2.

\section{Discussion}

Plant extracts used against crop pathogens have shown many properties which make them an alternative to be used as synthetic pesticides (Zirihi et al., 2008; Zakaria et al., 2020). From the result, the effectiveness of $A$. mannii seed extracts on the in vitro growth of two strains of $C$. lindemuthianum and $F$. solani was studied.

Although studies on traditional medicine have shown the bactericidal and antimicrobial activity of A. mannii leaf, root and stem extracts (Donfack et al., 2014), the antifungal activity of $A$. mannii seed extracts is poorly documented. The results of the extraction of $500 \mathrm{~g}$ of $A$. mannii powder show a variation in yield according to the solvents used, with a yield of $32.89 \%$ with methanol higher than $25.40 \%$ obtained with water in this study. This variation in yield could be due to the state of the plant material at the time of collection, the plant cycle and the environmental conditions. Using leaves of Moringa oleifera and using seeds of Thevetia peruviana, Okumu et al. (2016) and Essomé et al. (2020), respectively, reported that extraction yields were better with methanol than water. Phytochemical analysis of the extracts showed the presence of numerous secondary compounds such as alkaloids, phenols, saponins, sterols and triterpenes. According to Boulogne (2011), Boulenouar (2011), Okumu et al. (2016), Zouaoui et al. (2018), Kossonou et al. (2019) and Essomé et al. (2020), the molecules mostly responsible for antifungal activity are phenolic compounds, terpenoids and alkaloids respectively.

Antifungal activity of A. mannii seed extracts on strains 1 and 2 of $C$. lindemuthianum and $F$. solani pathogens was recorded. These extracts significantly reduced the development of colonies of $C$. lindemuthianum compared to the control. A concentration of $50 \mu 1 / \mathrm{ml}$ was the most effective in reducing the radial growth of the fungi. Studies have shown the fungistatic effect of methanolic and aqueous extracts of Cola gigantea on $F$. oxysporum and Colletotrichum sp. (Kossonou et al., 2019), Acacia raddiana and Asteriscus graveolens (Boulenouar, 2011), Euphorbia sp. (Hajji et al., 2016).

The inhibition percentages of plant extracts increased according to the concentrations used and the nature of the solvent. At the highest concentration $(50 \mu \mathrm{l} / \mathrm{ml})$, the extracts did not kill the pathogen strains as was seen with the fungicide, but showed a slow radial growth. On the other hand, a complete inhibition of radial growth can be obtained with an increase in concentration of extracts. Kone et al. (2018) obtained inhibited growth of Cercospora malayensis with different solvents at the concentration of $120 \mu \mathrm{l} / \mathrm{ml}$ for the extracts of Jatropha curcas.

Kossonou et al. (2019) showed the fungistatic activity of plant extracts on $F$. oxysporum and Colletotrichum sp. In this study, the aqueous extract showed an inhibition percentage of $72.71 \%$ on $F$. solani. Similarly, Doga et al. (2017) showed that aqueous extract of Crotalaria retusa had an inhibition rate of $92.04 \%$ on $F$. solani while Obi and Barriuso (2013) showed that aqueous extract of Xylopiaa ethiopica (Annonaceae) inhibits the growth of colonies of Colletotrichum destructivum. Furthermore, Znaïdi (2020) showed that extracts from compost inhibit the growth of $F$. solani in Tunisia. With regard to the minimum inhibition concentrations $\mathrm{MIC}_{50}$ and $\mathrm{MIC}_{90}$, the organic extracts were more effective than the aqueous extract showing their high fungistatic properties. Low MICs of the acetone extract on $C$. lindemuthianum and the methanol extract on $F$. solani show their effectiveness. Doumbouya et al. (2012) showed that the low MIC 
values of Ocimum gratissimum extracts would induce an inhibition of growth and development of phytopathogenic fungi.

\section{Conclusions}

Many research works have shown the therapeutic and medicinal uses of $A$. mannii in tropical Africa. This work has shown the remarkable and significant antifungal power of this plant against two most dreaded cryptogams of common bean crop. A. mannii seed extracts contain active substances that significantly inhibit the radial growth of $C$. lindemuthianum and $F$. solani strains in six days of incubation. It would be interesting to test A. mannii seed extracts on other phytopathogenic agents in order to determine the action spectrum for the development of an alternative to synthetic fungicides without harmful effects on human health and environment.

\section{Conflict of interest statement}

Authors declare that they have no conflict of interest.

\section{Acknowledgement}

The authors would like to thank the heads of the Biotechnology and Environment laboratories (Research Unit: Phytopathology and Plant Protection) and the Organic Chemistry department of the University of Yaoundé 1 for their support and the provision of the equipment needed to carry out this work.

\section{References}

Ademe, A., 2013. Evaluation of antifungal activity of plant extracts against Papaya Anthracnose (Colletotrichum gloeosporioides). J. Plant Pathol. Microbiol., 4(10): 207.

Adjou, E.S., Soumanou, M. M., 2013. Efficacité des extraits de plantes dans la lutte contre les moisissures toxinogènes isolées de l'arachide en post-récolte au Bénin. J. Appl. Biosci., 70: 55555566.

Alleche, N., 2017. Activité antifongique de quelques extraits d'une plante endémique sur des moisissures du blé stocké. Mémoire de Master. Université des Frères Mentouri Constantine, Algérie. 82p.

Ambang, Z., 1996. Efficacité de nouveaux pesticides contre le mildiou du doryphore de la pomme de terre, leur action sur les tissus de la plante. Thèse de PhD. Université de Russie de l'Amitié des peuples, Moscou. 128p.

Ambang, Z., Ndongo, B., Amayana, D., Djilé, B., Ngoh, J. P., Chewachong, G. M., 2009. Combined effect of host plant resistance and insecticide application on the development of cowpea viral diseases. Austr. J. Crop Sci., 3(3): 167-172.

Ambang, Z., Ngoh Dooh, J. P., Essono, G., Bekolo, N., Chewachong, G., Asseng, C. C., 2010. Effect of Thevetia peruviana seeds extract on in vitro growth of four strains of Phytophthora megakarya. Plant Omics J., 3(6): 204-209.

Autrique, A., Perreaux, D., 1989. Maladies et ravageurs des cultures de la région des grands lacs d'Afrique Centrale. AGCD-Coopération Belge, $\mathrm{N}^{\circ} 24$. 232p.

Betti, J. L., 2002. Medicinal plants sold in Yaounde markets Cameroon. Afr. Study Monogr., 23(2): 47-64.

Boulenouar, N., 2011. Substances naturelles à visée antifongique: cas particulier des polyphénols. Thèse de Doctorat. Université d'Oran. Algérie. $182 \mathrm{p}$.

Boulogne, I., 2011. Evaluation du potentiel insecticide et antifongique sur Acromyrmex octospinosus (Reich) d'une sélection de plantes à usages ethnopharmacologiques TRAMIL. Thèse en biologie. Université des Antilles et de la Guyane. $183 \mathrm{p}$.

Brooks, F.E., 2005. Taro leaf blight. The Plant Health Instructor. DOI: 10.1094/PHI-I-2005-0531-01. Updated 2015.

CIAT, 2006. Le haricot vert, source de revenu pour les petits agriculteurs d'Afrique de $1^{\prime} E s t . \mathrm{N}^{\circ} 31$. Le CIAT en Afrique.

Coleman, J. J., 2016. The Fusarium solani species complex: Ubiquitous pathogens of agricultural importance. Mol. Plant Pathol., 17: 146-158.

CTNBC, 2020. Comité Technique National de la Balance Commerciale (CTNBC) - Cellule des Statistiques du Ministère du Commerce, Cameroun.

Dibong, S. D., Mvogo, O. P. B., Vandi, D., Ndjib, R. C., Monkam, T. F., Mpondo, M. E., 2015. Ethnobotanique des plantes médicinales anti hémorroïdes des marchés et villages du Centre et du Littoral Cameroun. J. Appl. Biosci., 96: 90729093.

Djeugap J.F., Fontem D.A. et Taondjou AL., 2009. Evaluation des milieux de culture pour la croissance de Phythora infestans, agent causal du 
mildiou chez la morelle noire. iBiosci. Proc., 15: 85-92.

Doga, D., Zirihi, G.N., Zézé, A., 2016. Propriétés antifongiques des légumineuses médicinales de Côte d'ivoire: cas de Crotalaria retusa L. (Fabaceae) sur la croissance in vitro de Phytophthora sp. Et Fusarium solani, deux champignons phytopathogènes. Eur. Scient. J., 13(3): 371-384.

Dohou, N., Badoc, A., Douira, A., 2004. Activité antifongique de Thymelea lythroides sur trois champignons du riz. Bull. Soc. Pharm. Bordeaux. 143: 31-38.

Donfack, V. F. D., Roque, S., Trigo, G., Fokou, P. V. T., Tchokouaha, L. R. Y., Tsabang, N., Zollo, P. H. A., Correia-Neves, M., Fekam, B. F., 2014. Antimycobacterial activity of selected medicinal plants extracts from Cameroon. Int. J. Biol. Chem. Sci., 8(1): 273-288.

Doumbouya, M., Abo, K., Lepengue, H. N., Camara, B., Kanko, K., Aidara, D., Kone, D., 2012. Activité comparés in vitro de deux fongicides de synthèses et de deux huiles essentielles sur les champignons telluriques des cultures maraichères en Côte d'Ivoire. J. Appl. Biosci., 50: 3520-3532.

Edeoga, H. O., Okwu, D. E., Mbaebie, B. O., 2005. Phytochemical constituents of some Nigerian medicinal plants. Afr. J. Biotechnol., 4(7): 685688.

Essomé, S. C., Ngoh Dooh, J. P., Heu, A., Ndogho, A., Ngatsi, Z. P., Chewachong, G., Ambang, Z., 2020. Evaluation des activités antifongiques des extraits de graines de Thevetia peruviana contre Phytophthora colocasiae (Oomycètes) agent causal du mildiou du taro (Colocasia esculenta (L.) Schott) au Cameroun. J. Appl. Biosci., 151: 15584-15597.

FAO, 2020. FAOSTAT: Données de l'alimentation et de l'agriculture. http://www.fao.org/faostat /fr/\#data/QC(visited october 7 2020).

Faucher, R. S., Bourget, N., Thibaudeau, S., Duval, B., Mathieu, S., Breton, A. M., O’Donoughue, L., 2018. Evaluation de maladies racinaires du soja dans des champs de la Montérégie en 2014 et 2015. Érudit. Rev. Phytoprotection, 98(1), 1-50.

Finney, D. F., 1971. Probits Analysis (3rd Edn.). University Press, Cambridge.

Hajji, H., Tallal, I., Maafa, I., Bentata, F., El Alaoui Faris, F. E., Abdennebi, El., El Aissami, A., 2016. Evaluation in vitro de l'activité antifongique de quatre plantes médicinales marocaines sur cinq champignons phytopathogènes. Rev. Maroc. Prot. Plant., 10: 57-65.

Harbone, J., 1973. Phytochemical methods. A guide to modern techniques of plant analysis Chapman and Hall, London, 150p.

Houndahouan, T. E. D., Zannou, A., Sikirou, R., Adomou, A., Zinsou, V., Boukari, S., N'djolossè, K., 2018. Les pertes économiques dues à l'anthracnose de l'anacardier au Bénin. Eur. Scient. J., 14(15): 127-138.

IRAD, 2013. Contribution de la recherche à l'amélioration de la production et la consommation des légumineuses alimentaires au Cameroun. Projet C2D Légumineuses.

Jiofack, T., Ayissi, I., Fokunang, C., Guedje, N., Kemeuze, V., 2009. Ethnobotany and phytomedicine of upper Nyong valley forest in Cameroon. Afr. J. Pharmacol., 3(4): 144-150.

Katan, J., 2017. Diseases caused by soilborne pathogens: Biology, management and challenges. J. Plant Pathol., 99: 305-315.

Kebede, E., Yildiz, F., 2020. Grain legumes production and productivity in Ethiopian smallholder agricultural system, contribution to livelihoods and the way forward. Cogent Food Agric., 6: 1, DOI: 10.1080/23311932.2020.1722353

Kimberly, Z. A., Oladzadabbasabadi, A., Shalu, J., Odderman, C., Osorno, J. M., McClean, P. E., Pasche, J. S., 2020. Sources of resistance to Fusarium solani and associated genomic regions in common bean diversity panels. Front. Genet., 11: 475 .

Konda, K. M., Kabkura, M., Mbembe, B., Itufa, Y., Mahuku, K., Mafuta, M., Mpoyi, K., Ndemankeni, I., Kadima, K., Kelela, B., Ngiuvu, V., Bongombola, M., Dumu, L., 2012. Plantes médicinales de traditions Province de l'EquateurRD Congo. Institu de Recherche en Sciences de la Santé, Kinshasa. 420p.

Kone Nsangou, A. N., Ndongo Bekolo, Mountapmbeme, M. M., Manga Essouma, F. R., Heu, A., Mvondo Nganti, D., Mboussi, S. B., Ambang, Z., 2018. Anti-fungical activities of Jatropha curcas seeds extracts against Cercospora malayensis causative agent of sigatoka of okra leaves. Int. J. Sci. Res. Methodol., 9(1): 95-109.

Kossonou, Y. K., Kouakou-Kouame, A. C., Koffi, A. C., Koffi, Y. M., Tra Bi fézan, H., Tano, K., 2019. Antifungal in vitro activity of five plants 
from local traditional medecine of Côte d'Ivoire on Colletotrichum higginsianum, Fusarium oxysporum and Rhizopus stolonifer, pathogens of pawpaw (Carica papaya L.) and tomatoes (Solanum lycopersicum L.). Eur. Scient. J., 15(9): 1857-1874.

Kwowura, K., Sowley, E., Badii, K. B., 2019. Antifungial activity of plant extracts against Colletotrichum gloeosporioides (Penz.) the causative agent of yam anthracnose disease. Arch. Phytopathol. Plant Prot., 52(4): 1-16.

LeClair, E., Conner, R. L., Robinson, D. E., Gillard, C. L., 2015. Transmission de l'anthracnose (Colletotrichum lindemuthianum) chez le haricot (Phaseolus vulgaris L.) au moyen d'un inoculum artificiel ou naturel sous feuillage humide ou sec. Can. J. Plant Sci., 95(5): 913-921.

Meddah, N., Ouazzani, T. A., Benkirane, R., Douira, A., 2011. Étude du pouvoir pathogène de quelques espèces de Fusarium sur le bananier sous serre au Maroc. Bull. Soc. Roy. Sci. Liège, 80: 939-952.

Mokale, K. A., Kopa, K. T., Pradeep, P., Prem, N., 2020. Pharmacological evidence of Vitex thyrsiflora, Entandrophrgma cylindricum, and Anonidium mannii used for the management of inflammation in Cameroon. J. Basic Clin. Physiol. Pharmacol., 31(4). DOI: 10.1515/jbcpp2019-0053.

Mukamuhirwa, F., Butare, L., Ruhakana, A., Uzayisenga, B., Mukantwali, C., Musoni, A., Mukankusi, C., 2018. Characterization and pathogenicity of soil borne pathogens inducing root rot symptoms in common bean in Rwanda. Int. J. Scient. Res. Manage., 6(4): 89-100.

Mukankusi, M. C., 2008. Improving resistance to Fusarium root rot [Fusarium solani (Mart.) Sacc. f. sp. phaseoli (Burkholder) W.C. Snyder \& H.N. Hans.] in Common bean (Phaseolus vulgaris L.). Thèse de Doctorat PhD. University of KwaZuluNatal, Pietermaritzburg, South Africa. 202p.

Ngoh Dooh, J. P., Ambang, Z., Ewola, T. A., Heu, A., Kosma, P., Maho, Y. J. E., Goghomu, T. R., 2014. Screening and the effect of extracts of Thevetia peruviana on the development of Colletotrichum gloeosporioides, causal agent of cassava anthracnose disease. J. Agric. Res. Dev., 4(4): 54-65.

Nyeguea, M., Amvam-Zollo, P.H., Etoa, F. X., Agnanietb, H., Menut, C., 2008. Chemical and biological investigations of essential oils from stem barks of Enantia chlorantha Oliv. and
Polyalthia suaveolens Engler. \& Diels. from Cameroon. Nat. Prod. Commun., 3(7): 10891096.

Obi, V. I., Barriuso-Vergas, J. J., 2013. Effects of some botanicals on Colletotrichum destructivum O'Gara of cowpea. Afr. J. Microbiol. Res., 7(37): 4576-4581.

Okumu, M. O., Mbara, J. M., Kanja, L. W., Gakuya, D. W., Kiama, G., Ochola, F. O., 2016. Phytochemical profile and antioxidant capacity of leaves of Moringa oleifera (Lam.) extracted using different sovent systems. J. Pharmacogn. Phytochem., 5(4): 302-308.

Ondo, A. S., 2006. Caractérisation de quelques isolats de $P$. megakarya agent causal de la pourriture brune des cabosses de cacaoyer (Theobroma cacao L.). Mémoire de DEA, Université de Yaoundé I, 58p.

Paluku, A., Bwama, M., Okungo, A., Tchoundjeu, Z., Van Damme, P., 2019. Production de plants d'Anonidium mannii (Oliver) Engler \& Diels par la multiplication végétative. Rev. Mar. Sci. Agron. Vét., 7(1): 129-136.

PROTA, 2015. Phaseolus vulgaris - Haricot sec. https:// uses.plantnet-project.org/f/Phaseolus_vulgaris_ haricot_sec(PROTA)\&oldid=95339. Cité le 6/10/2020.

Rakotoarimanga, Zananirina, J., Ramamonjisoa, D., Ramanankierana, H., 2014. Lutte biologique antifongique: actinomycètes du sol rhizosphérique antagonistes de Fusarium isolé du fruit de tomate (Solanum lycopersicum L., 1753) pourri. Afr. Sci., 10(3): 243-255.

Sarkhosh, B., Schaffer, A. I., Vargas, A. J., Palmateer, P., Lopez, A., Soleymani, Farzaneh, M., 2018. Antifungal activity of five plant-extracted essential oils against anthracnose in papaya fruit. Biol. Agric. Horticult., 34(1): 18-26

Schneider, K. A., Grafton, K. F., Kelly, D. J., 2001. Analysis of resistance to Fusarium root rot in bean. Crop Sci., 41(2): 535-542.

Scot, N., Brooks, F. E., Glenn, T., 2011. Taro leaf blight in Hawaiii. University of Hawaiii at Mänao, Plant Dis., 71: 1-4.

Snapp, S., Rahmanian, M., Batello, C., 2018. Légumes secs et exploitations durables en Afrique subsaharienne. FAO, Rome. 55p.

Stoll, G., 1994. Protection naturelle des végétaux en zone tropicale. CTA, Agrecol, pp.95-99.

Tsopmbeng, G. R., Fontem, D. A., Yamdé, K. F., 2012. Evaluation of culture media for growth and 
sporulation of Phytophthora colocasiae Racid., causal agent of taro blight. Int. J. Biol. Chem. Sci., 6(4): 1566-1573.

Wakesho, M. A., Pixley, K., Kipsumbai, E. K., Olubayo, F., Ochieng, J. W., 2008. Analysis of Kenyan isolates of Fusarium solani f. $s p$. phaseoli from common bean using colony characteristics, pathogenicity and microsatellite DNA. Afr. J. Biotechnol., 7(11): 1662-1671.

Zakaria, A. B., Mohamed, M., 2020. In vitro and in vivo, biocontrol activity of extracts prepared from Egyptian indigenous medicinal plants for the management of anthracnose of mango fruits. Arch. Phytopathol. Plant Prot., 53(15-16): 715-730.

Zirihi, G. N., Sora, S., Konee, D., Kouadio, Y. J., 2008. Activité antifongique de l'extrait naturel de
Combretum sp. in vitro sur 3 espèces fongiques telluriques des cultures de tomate en Côte d'Ivoire. Rev. Ivoir. Sci. Technol., 11: 131-142.

Znaïdi, I. E. A., 2002. Etude et évaluation du compostage de différents types de matières organiques et des effets des jus de composts biologiques sur les maladies des plantes. Master of Science degree, Mediterranin Agronomic Institute of Bari. 104p.

Zouaoui, S. A., Megherbi-Benali, A., Toumi, B. F., Ouaar, D., 2018. Contribution à l'étude du pouvoir antifongique des graines du Chenopodium quinoa wild vis-à-vis de deux champignons phytopathogènes de l'orge: Pyrenophora tritici-repentis et Rhynchosporium secalis. Bull. Soc. Roy. Sci. Liège, 87: 100-111.

\section{How to cite this article:}

Manga Anaba Désiré, Ndongo Bekolo, Biye Elvire Hortense, Kuate Tueguem William Norbert, Ngatsi Zemko Patrice, Ngono Ambassa Véronique. 2021. Effectiveness of Anonidium mannii seed extracts against Colletotrichum lindemuthianum and Fusarium solani, agents responsible for anthracnose and fusariose of common beans (Phaseolus vulgaris L.) in the Centre region-Cameroon. Int. J. Curr. Res. Biosci. Plant Biol., 8(2): 23-33.

doi: https://doi.org/10.20546/ijcrbp.2021.802.003 